\title{
STUDI TENTANG HABITAT DAN PENDUGAAN POPULASI KUSKUS BERTOTOL BIASA (SPILOCUSCUS MACULACTUS DESMAREST, 1803) DI PULAU NUMFOR KABUPATEN BIAK NUMFOR
}

\author{
Ihsan Febriadi \\ Fakultas Pertanian Universitas Al Amin - Sorong
}

\begin{abstract}
ABSTRAK
This study aims to determine the population of spotted cuscus (Spilocuscus maculatus) in the Numfor island of Biak Numfor District. The results showed, that the cuscus population density in sample area is 24 individuals per 87.5 ha with individual density 0.70 per ha. From this number $72.73 \%$ are adult individuals while the rest are individual adolescents and baby respectively $18.18 \%$ and $9.09 \%$. Distribution of individuals according to sex showed that $54.54 \%$ were male individuals and $45.45 \%$ female. Vegetation on the island Numfor is primary forest that has reached a climax so that a continuous tree canopy at a level that affects the low density, frequency and dominance of vegetation below it (pole level vegetation, saplings and seedlings). Vegetation levels were 26 species of trees in the dominance Intsia sp., Palaquium amboinensis and Decaspermum fructiosom, as many 24 species of small trees dominated by Canarium hiersetum, Aglaia sp., and Palaquium amboinensis, of saplings of 20 species and dominated Palaquium lobianum, Lepiniopsis ternatensis and Sterculia silinglawi and Seedlings as many 23 species dominated by Aglaia sp., Intsia sp., Pimelodenron amboinicum and Pometia sp.

Kata kunci: Populasi Kuskus, Habitat, Pulau Numfor
\end{abstract}

\section{ABSTRACT}

The results of this research revealed that population density of spotted cuscus was 11 individual per 35 ha which individual density was 0.31 per ha. From that number $72.73 \%$ was adult individual followed by adolescent $18.18 \%$ and baby $9.09 \%$. Otherwise, individual distribution according to sex revealed that $54.54 \%$ was male individual and $45.45 \%$ was female. The levels of vegetation in Numfor primary forest were trees, poles, saplings and seedlings. Trees level was 26 species dominated by Intsia sp, Palaquium amboinensis and Decaspermum fructiosom.Poles level was 24 species dominated by Canarium hiersetum, Aglaia sp., and Palaquium amboinensis. Saplings level was 20 species dominated by Palaquium lobianum, Lepiniopsis ternatensis and Sterculia silinglawi then seedlings level was 23 species dominated by Aglaia sp., Intsia sp., Pimelodenron amboinicum and Pometia sp.

Keywords : Population of cuscus, Habitat, Numfor Island

\section{PENDAHULUAN}

Kuskus berasal dari famili Phalangeridaedan merupakan marsupial Australia dan penyebaran satwa ini cukup luas, dimulai dari bagian timur Indonesia, Papua New Guinea, Cape York hingga Queensland di Australia. Namun secara mendalam mengenai perilaku, penyebaran dan jenisnya belum diketahui secara pasti
(Menzies, 1991). Disebutkan bahwa dari 11 jenis kuskus yang terdapat di New Guinea 7 jenis kuskusyaitu Spilocuscus maculatus),S. rufoniger,S.papuensis, Phalanger orientalis, $P$. gymnotis, $P$. vestitus (Sinery, 2010).Disamping termasuk satwa mamalia berkantung endemik di Papua, kuskus juga merupakan satwa yang memiliki karakter morfologi yang mempesona 
dengan wilayah penyebaran terbatas sehingga menjadi dasar penetapannya sebagai satwa yang dilindungi oleh pemerintah melalui Keputusan Menteri Pertanian No. 247/KPTS/UM/4/1979. Kuskus juga dilindungi oleh Peraturan Pemerintah No. 7 tahun 1999 tentang Pengawetan Jenis Tumbuhan dan Hewan dan secara global dua jenis di antaranya telah terdaftar dalam Appendix IIConvention on International Trade in Endangered Species of Wild Fauna and Flora (CITES)

Pulau Numfor dengan luas wilayah 1.806 ha merupakan salah satu pulau dengan kekayaan sumberdaya alam yang cukup tinggi. Sebagai salah satu wilayah terisolasi, Pulau Numfor memiliki keanekaragaman hayati dengan tingkat endemisitas yang cukup tinggi terutama untuk jenis-jenis burung sehingga pulau ini menjadi daerah endemik burung. Sinery (2002) menyebutkan bahwa jenis kuskus yang terdapat di Pulau Numfor adalah kuskus bertotol (marga spilocuscus) yaitu kuskus totol biasa (Spilocuscus maculatus) dengan tingkat pemanfaatanyang cukup tinggi namun hingga saat ini populasinya belum diketahui.

Hutan di Pulau Numfor dimanfaatkan oleh masyarakat untuk keperluan pertanian, perkebunan, bahan bangunan dan keperluan lainnya (perahu, pagar dan sumber energi). Kerusakan akibat aktivitas masyarakat ini dapat mengakibatkan terjadinya fragmentasi habitat kuskus. Kuskus cenderung hidup beradaptasi pada hutan lebat, namun dengan pembukaan hutan menyebabkan kuskus dapat bermigrasi ke wilayah lain. Di samping itu tingginya tingkat perburuan terhadap kuskus disertai dengan laju pembukaan areal hutan yang semakin tinggi di pulau ini dikhawatirkan akan terjadi penurunan populasi bahkan dapat mengakibatkan kepunahan spesies ini di masa mendatang. Oleh karena itu perlunya dilakukan studi mengenai populasi agar dapat menjadi sumber informasi dalam upaya pengelolaan yang dapat dilakukan untuk perlindungan dan pelestarian kuskus di Pulau Numfor.

\section{METODOLOGI PENELITIAN}

\section{Pelaksanaan Penelitian}

Penelitian ini dilaksanakan di Pulau Numfor Kabupaten Biak Numfor Provinsi Papua dan berlangsung selama2 bulan. Objek yang diamati dalam penelitian ini adalah populasi kuskus dan vegetasi hutan sebagai habitat kuskus yang terdapat di kawasan hutan Pulau Numfor Kabupaten Biak Numfor Provinsi Papua, sedangkan alat dan bahan yang digunakan adalah peta lapangan, kompas, perangkap atau jerat (cage trap), meteran, lampu senter, stop watch, sarung tangan, Global Positioning System (GPS), clinometer, haga meter, tongkat ukur, phiband, timbangan, kunci identifikasi jenis kuskus, peralatan dokumentasi (camera digital dan video camera), tally sheet dan kalkulator.

Pelaksanaan penelitian terdiri atas beberapa tahapan kegiatan, yaitu:

\section{Tahapan Penelitian}

1) Penetuan areal penelitian dan transek, untuk menduga populasi kuskus dibuat 2 transek dengan luas 35 ha. Lokasi penelitian di pulau numfor ditentukan secara purposive dengan melihat secara subjektif pada areal vegetasi hutan yang masih baik. Kemudian transek pada lokasi penelitian diposisikan tegak lurus baseline (base line berupa jalan raya) sebanyak 2 transek dengan jarak 200 $\mathrm{m}$ antar transek, dimulai denganjarak 100 $\mathrm{m}$ dari base line sejajar garis pantai dari arah barat ke timur.Masing-masing transek berukuran $3500 \mathrm{~m}$ dan lebar transek sesuai jarak pandang minimal $\pm 50 \mathrm{~m}$.

2) Pengamatan populasi kuskus, dilakukan melalui pendekatan pengamatan langsung dalam jalur. Pengamatan secara langsung dilakukan serentak oleh 2 kelompok. Masing-masing kelompok terdiri atas minimal 3 orang ( 1 orang pencatat, 1 orang pengukur jarak objek, 1 orang pengenal jenis). Frekuensi pengamatan 2 kali dengan selang waktu 2 minggu dalam 1 bulan. Survei dilakukan malam hari (jam 19.00 sampai 05.00 WIT). 
3) Penangkapan dan Pengukuran morfologi

kuskus, dalam penelitian ini dipasang juga sejumlah pada 2 jalur pengamatan (transek). Tujuan pemasangan perangkap adalah untuk memperoleh contoh kuskus yang nantinya digunakan dalam pengukuran morfologi kuskus. Jumlah perangkap yang dipasang sebanyak 10 buah masing-masing transek. Penempatan perangkap dilakukan secara purposive dekat dengan pohon pakan kuskus yang teridentifikasi dalam transek. Pengukuran morfologi kuskus meliputi panjang tubuh menggunakan meteran dan dinyatakan dalam mili meter $(\mathrm{mm})$, berat tubuh menggunakan timbangan dalam gram (gr). Data hasil deskripsi morfologi jenis kuskus dicatat pada tally sheet dan dilanjutkan dengan klasifikasi umur kuskus.

4) Inventarisasi vegetasi, pengambilan data struktur dan komposisi vegetasi sebagai pendukung populasi kuskus dilakukan melalui metode jalur (strip sampling). Inventarisasi meliputi vegetasi pakan dan vegetasi non pakan sekitar tingkat semai (tinggi $\leq 1,5 \mathrm{~m}$ ) petak $2 \times 2$ $\mathrm{m}$, tingkat pancang (tinggi $1,5 \mathrm{~m}-\leq 10 \mathrm{~cm}$ ) petak $5 \times 5 \mathrm{~m}$, tiang (diameter $11-19 \mathrm{~cm}$ ) petak $10 \times$ $10 \mathrm{~m}$ dan pohon (diameter $\geq 20 \mathrm{~cm}$ ) petak $20 \mathrm{x}$ $20 \mathrm{~m}$. Jalur pengamatan yang dibuat sebanyak 2 jalur dengan panjang jalur $1000 \mathrm{~m}$ dan jarak antar jalur $200 \mathrm{~m}$, masing-masing jalur dibuat 10 petak pengamatan. Profil vegetasi, Untuk mengetahui gambaran tutupan vegetasi pada lokasi penelitian, maka dibuat profil diagram vegetasi. Pembuatan plot penelitian dilakukan secara purposive pada masing-masing jalur pengamatan. Plot yang dibuat berupa plot tunggal berukuran $100 \mathrm{~m} \mathrm{x}$ $20 \mathrm{~m}$. Proyeksi tutupan vegetasi, diukur hanya untuk tingkat pohon yaitu (diameter $\geq 20 \mathrm{~cm}$ ) dan dilakukan dengan mengukur luas proyeksi tajuk. Pengukuran tinggi tajuk menggunakan clinometer atau haga dan tongkat ukur sedangkan lebar tajuk menggunakan meteran pada kedua sisi (kanan-kiri / utara selatan-timur barat).

\section{Analisis Data}

Data yang dikumpulkan dianalisis secara statistik dan ditampilkan dalam bentuk tabel dan gambar (bagan, grafik dan foto).

\section{HASIL DAN PEMBAHASAN}

\section{Populasi Kuskus}

Berdasarkan hasil pengamatan terhadap kehadiran individu kuskus melalui metode jalur (transek), diketahui bahwa kawasan hutan Pulau Numfor memiliki populasi kuskus yang cukup besar. Hasil analisis seperti terlihat pada Tabel 1 menunjukkan, bahwa kepadatan populasi kuskus di kawasan hutan Pulau Numfor yang diestimasi adalah sebesar 10,81 atau 11 individu. Nilai tersebut menggambarkan bahwa dalam luas 35 ha terdapat sebanyak kurang lebih 0,31 individu/ha atau setiap individuhanya menguasai areal seluas hampir 3,31 ha.

Tabel 1. Perkiraan Kepadatan Populasi Kuskus di Pulau Numfor

\begin{tabular}{cccc}
\hline Jumlah & $\begin{array}{c}\text { Jumlah } \\
\text { individu } \\
\text { transek }\end{array}$ & $\begin{array}{c}\text { Rataan jarak } \\
\text { tegak lurus } \\
\text { kuskus dari } \\
\text { transek } \\
(\mathrm{Y})\end{array}$ & $\begin{array}{c}\text { Perkiraan } \\
\text { populasi } \\
(\mathrm{P})\end{array}$ \\
\hline 2 & 8 & 18,5 & 10,81 \\
\hline
\end{tabular}

Pulau Numfor dipengaruhi oleh berbagai faktor, baik faktor yang berasal dari dalam (internal factor) yaitu kondisi populasi itu sendiri maupun yang berasal dari luar (external factor) yaitu faktor lingkungan. Kondisi populasi dimaksud tersebut meliputi kemampuan populasi untuk tumbuh dan berkembang yang dipengaruhi oleh kemampuan masing-masing individu. Kemampuan masingmasing individu tersebut dipengaruhi faktor-faktor keturunan. Kondisi populasi juga dipengaruhi oleh faktor lingkungan seperti ketersediaan makanan, ruang dan keamanan tempat berkativitas (habitat).

\section{Struktur Populasi}

Hasil deskripsi selanjutnya ditabulasikan menurut jenis kelamin dan kelas umur guna menggambarkan distribusi individu kuskus berdasarkan jenis kelamin dan kelas pertumbuhan yang meliputi tingkat anak, remaja dan dewasa sebagaimana terlihat pada Tabel 2. 
Tabel 2. Struktur Populasi Kuskus di Pulau Numfor t Kabupaten Biak Numfor.

\begin{tabular}{|c|c|c|c|c|}
\hline \multirow{2}{*}{$\begin{array}{l}\text { Kelas } \\
\text { umur }\end{array}$} & \multicolumn{2}{|c|}{ Jenis kelamin } & \multirow{2}{*}{$\begin{array}{l}\text { Individu } \\
\text { (ni) }\end{array}$} & \multirow{2}{*}{$\begin{array}{c}\text { Persentase } \\
(\%)\end{array}$} \\
\hline & Jantan & Betina & & \\
\hline Anak & 1 & - & 1 & 9,09 \\
\hline Remaja & 1 & 1 & 2 & 18,18 \\
\hline Dewasa & 4 & 4 & 8 & 72,73 \\
\hline Jumlah & 6 & 5 & 11 & 100 \\
\hline
\end{tabular}

Pada Tabel 2, terlihat bahwa dari 11

individu yang diidentifikasi 54,55\% diantaranya berjenis kelamin jantan dan $45,45 \%$ berjenis kelamin betina. Perbandingan jenis kelamin kuskus jantan dan betina hampir seimbang walaupun jumlah jantan sedikit lebih banyak. Pada Tabel tersebut juga terlihat bahwa, jumlah individu yang diidentifikasi 11 individu diantaranya 8 individu berada pada kelas umur dewasa sedangkan sisanya tergolong kelas umur remaja dan anak masing-masing 2 dan 1 individu. Data tersebut menunjukkan bahwa jumlah individu kuskus umur dewasa lebih banyak dibandingkan dengan individu yang berumur remaja dan anak. Keberadaan individu dewasa, baik jantan maupun betina merupakan kondisi yang baik dari aspek konservasi karena berpotensi dalam proses reproduksi dan regenerasi populasi. Kondisi tersebut dapat saja terjadi bila komponen lingkungan yang berpengaruh terhadap populasi kuskus dapat dikendalikan atau dipertahankan seperti bahaya perburuan, ketersediaan pakan dan ruang. Selanjutnya dengan adanya individu yang berada pada kelas umur remaja dan anak akan menjadi penentu eksistensi populasi dalam proses pertumbuhan dan perkembangan di masa mendatang.

Berdasarkan seks rasio pada populasi yang dijumpai dalam penelitian ini, dapat dikatakan bahwa populasi kuskus di Pulau Numfor memiliki prospek yang cukup baik untuk dapat survive dan berkembang biak di masa mendatang. Hal tersebut karena perbandingan seks rasio individu jantan dan betina dewasa yang ada mencukupi untuk terjadinya perkawinan (breeding) walaupun tingkat reproduksi rendah. Sebagaimana diketahui bahwa kuskus bersifat poligamy (berganti pasangan) namun memiliki reproduksi yang rendah. Hal tersebut sesuai dengan Sinery (2006) kuskus merupakan mamalia yang memiliki teritory area yang cukup kecil (4 individu/ha untuk kondisi hutan bagus) dan bersifat poligamy dengan usia hidup dapat mencapai 13 tahun. Disebutkan pula bahwa reproduksi kuskus yang rendah akibat rentang waktu menyusui atau memelihara anak (dalam kantung bayi) yang cukup lama (mencapai 6 bulan) walaupun memiliki masa kehamilan sampai beranak yang relatif lebih cepat (1,5 - 2 bulan).

\section{Morfologi Spilocuscus maculatus Asal Pulau Numfor}

Dari 20 perangkap yang dipasang pada transek, diperoleh 3 ekor kuskus yang terperangkap, 2 ekor diperoleh pada transek pertama dan 1 ekor pada transek kedua. Berdasarkan hasil pengamatan lapangan dan studi leteratur, diketahui bahwa kuskus yang terdapat di Pulau Numfor hanya satu jenis yaitu kuskus totol biasa/spotted cuscus (Spilocuscus maculatus). Kuskus ini merupakan jenis kuskus berukuran tubuh besar baik jantan maupun betina. Gambaran secara rinci tentang karakteristik morfologi Spilocuscus maculatus yang terdapat di Pulau Numfor dapat dilihat pada Tabel 3

Tabel 3. Rataan Morfometrik Jenis Kuskus di Lokasi Penelitian $(n=3)$

\begin{tabular}{clcc}
\hline \multirow{2}{*}{ No } & \multirow{2}{*}{$\begin{array}{c}\text { Komponen } \\
\text { ukuran }\end{array}$} & \begin{tabular}{c} 
Panjang organ tubuh \\
\cline { 3 - 4 }$(\mathrm{mm})$
\end{tabular} & $\begin{array}{c}\text { Betina } \\
(\mathrm{mm})\end{array}$ \\
\hline 1 & PT & 535,10 & 510 \\
2 & PK & 166 & 158,67 \\
3 & PB & 373 & 351,33 \\
4 & AM & 35 & 31,00 \\
5 & AK & 79 & 69,67 \\
6 & EBA & 337 & 332,00 \\
7 & EBB & 190 & 179,33 \\
8 & ETBA & 183 & 150,33 \\
9 & ETBB & 330 & 303,00 \\
10 & PEK & 142 & 137,33 \\
11 & PEL & 190 & 177,67 \\
12 & PE & 520,10 & 482,33 \\
13 & BT (gr) & 5524 & 4572 \\
\hline
\end{tabular}

Keterangan:

$\mathrm{PT}=$ Panjang tubuh(dari ujung jungur/anterior sampai pangkal ekor /inverior),

$\mathrm{PK}=$ Panjang kepala (dari ujung jungur sampai pangkal kepala /interparietal bone),

$\mathrm{PB}=$ Panjang badan (dari pangkal kepala sampai pangkal ekor/ kloaka), 
$\mathrm{AM}=$ Jarak kedua sudut kelopak mata,

AK = Jarak antara kedua kuping,

EBA = Panjang ekor berbulu bagian permukaan atas,

$\mathrm{EBB}=$ Panjang ekor berbulu permukaan bawah,

$\mathrm{ETBA}=$ Panjang ekor tidak berbulu bagian permukaan atas,

ETBB $=$ Panjang ekor tidak berbulu bagian permukaan bawah,

PEK = Panjang ekor tidak berbulu yang kasar / berbintil,

PEL = Panjang pemukaan ekor tidak berbulu yang terasa licin / tidak berbintil,

PTE = Panjang ekor (dari pangkal ekor sampai ujung ekor),

$\mathrm{BT}=$ Barat tubuh

\section{Panjang dan Berat Tubuh}

Hasil identifikasi menunjukkan, bahwa jantan $S$. maculatus asal wilayah ini memiliki panjang dan berat tubuh berkisar antara 512 sampai $550 \mathrm{~mm}$ dan 4.200 sampai 5.524 gram. Ukuran panjang dan berat tubuh betina berkisar antara 472 sampai $510 \mathrm{~mm}$ dan 3.352 sampai 4.572 gram.

\section{Warna Tubuh}

Data tersebut di atas menunjukkan bahwa $S$. maculatus yang terdapat di Pulau Numfor memiliki karakter morfologi yang tidak berbeda dari S. maculatus yang dijumpai di wilayah lain berdasarkan hasi-hasil penelitian sebelumnya. Bagian kepala jantan berwarna coklat muda menyebar dari pangkal hidung melalui interparietal bone ke arah belakang (posterior). Bulu bagian dorsal putih disertai totol coklat muda dari pangkal kepala ke arah belakang dengan warna totol semakin gelap (coklat tua). Warna ini menyebar ke arah samping badan sampai bagian luar kaki dan tangan dan batas ventral. Ventral berwarna coklat muda (krem) dari bagian bawah kepala sampai ujung ekor berbulu. Kepala betina berwarna coklat muda menyebar ke arah belakang (posterior) dan membentuk warna coklat kehitaman dari tengah badan (abdomen) sampai ke pangkal ekor. Warna ini menyebar ke arah samping menuju batas ventral dan sampai bagian luar kaki dan tangan. Bagian ventral seluruhnya berwarna coklat muda dari bawah kepala sampai ujung ekor berbulu disertai warna coklat muda kekuningan di sekitar kantong bayi. Jantan dan betina lainnya memiliki warna bulu yang sama yaitu keduanya berwarna putih atau krem. Kepala betina jenis ini biasanya berwarna putih menuju posterior dan membentuk warna cokelat muda (krem) di bagian posterior (tengah badan sampai pangkal ekor). Bulu di ventral betina ini berwarna coklat muda dan kadang berwarna putih dan disertai bercak kuning kecoklatan di sekitar kantong bayi.

Secara umum, bulu bagian ekor jantan dan betina dewasa Spilocuscus maculatus asal Pulau Numfor berwarna putih atau coklat muda. Warna tersebut terlihat dari pangkal ekor menuju ujung bagian ekor berbulu dengan warna yang makin terang ke arah bagian bawah ekor. Bagian ekor tidak berbulu berwarna coklat muda/krem. Warna tersebut akan tampak sama untuk tingkat pertumbuhan remaja, namun yang membedakan adalah ukuran tubuh. Warna bulu kuskus remaja baik jantan maupun betina yang bervariasi bulu putih, biasanya sudah tampak seperti kuskus dewasa namun memiliki ukuran tubuh lebih kecil $(<0,5 \mathrm{~kg})$ dengan ketebalan bulu yang lebih rendah. Pejantan kuskus totol biasa memiliki karakter bulu berwarna abu-abu seperti bulu betina tetapi sudah mulai terlihat spot-spot berwarna terang yang akan berwarna cokelat bila pada usia remaja atau cokelat kekuningan kontras pada usia dewasa. Karakteristik morfologi jantan dan betina kuskus totol biasa yang masih anakan terlihat berbeda bila dibandingkan yang remaja dan dewasa kecuali untuk yang berwarna putih keseluruhan tanpa totol masih tetap sama namun berbeda dalam hal kualitas ketebalan bulu.Pada beberapa bagian tubuh seperti pinggang bagian dalam, punggung dan leher terlihat seperti tidak berbulu/kosong namun sebenarnya terdapat bulu tetapi sangat tipis. Untuk variasi yang bertotol memiliki karakteristik bulu yang sangat berbeda yaitu didominasi warna putih atau cokelat namun belum tampak cokelat kemerahan atau cokelet kekuningan (betina) dan belum tampak totol coklat kemerahan atau kekuningan yang menjadi ciri dari jantan jenis ini. 


\section{Habitat Kuskus}

Kondisi vegetasi di pulau Numfor secara umum merupakan vegetasi hutan yang masih baik, hal ini ditunjukkan oleh adanya dominasi jenis dan individu melalui Indeks Nilai Penting (INP) yang mana tingkat pohon lebih tinggi diikuti tingkat tiang, semai dan pancang. Vegetasi tingkat pohon sebanyak 26 jenis di dominasi Intsia sp., Palaquium amboinensis dan Decaspermum fructiosom, tingkat tiang sebanyak 24 jenis didominasi Canarium hiersetum, Aglaia sp., dan Palaquium amboinensis, tingkat pancang sebanyak 20 jenis dan didominasi
Palaquium lobianum, Lepiniopsis ternatensis dan Sterculia silinglawi dan tingkat semai sebanyak 23 jenis vegetasi dominasi Aglaia sp., Intsia sp., Pimelodenron amboinicum dan Pometia sp.Kondisi tersebut bila dikaitkan dengan aspek konservasi, maka merupakan suatu kondisi yang cukup baik bagi keberadaan kuskus karena tersedianya sumber pakan yang cukup besar dan bervariasi. Karakteristik musim buah yang berbeda untuk masing-masing jenis maupun masing-masing pohon menjadi suatu hal yang sangat baik dari aspek ketersediaan sumber pakan kuskus dalam rentang waktu.
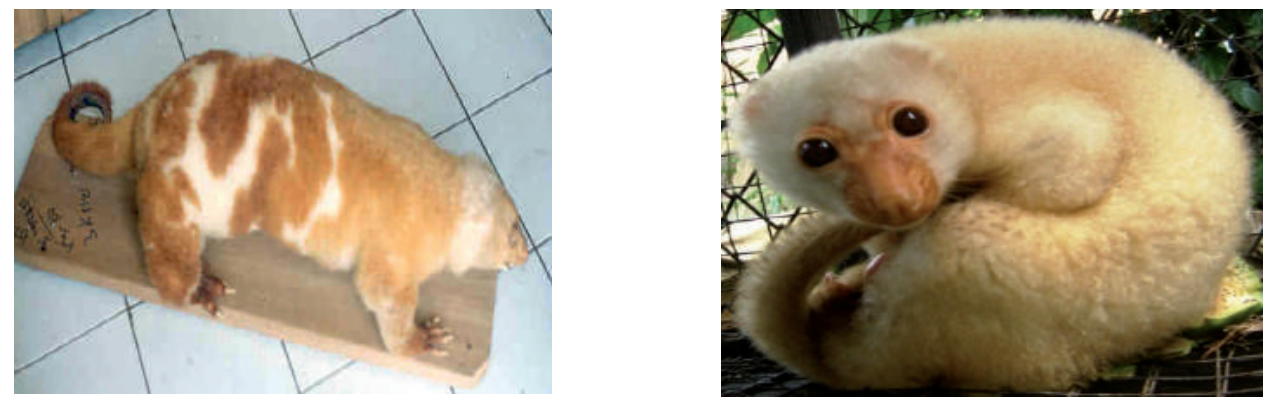

Gambar 1. Spilocuscus maculatus Jantan bertotol dan Betina Dewasa Asal Pulau Numfor
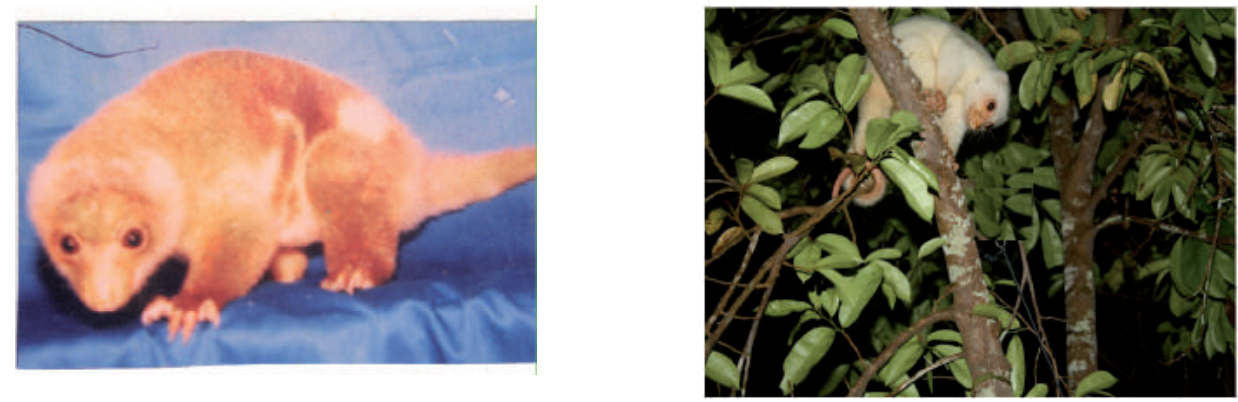

Gambar 2. Spilocuscus Maculatus Jantan bertotol dan Betina Remaja Asal Pulau Numfor

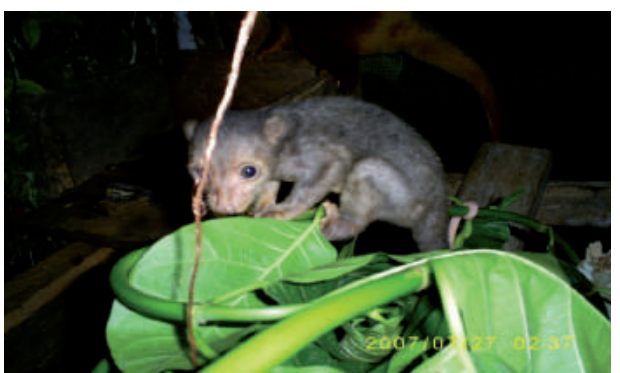

Gambar 3. Spilocuscus maculatus Betina (Anakan) 


\section{Vegetasi Pakan Kuskus}

Dari total 33 jenis vegetasi yang ditemukan dalam penelitian ini, 12 jenis $(36,36 \%)$ diantaranya merupakan vegetasi pakan kuskus.

Tabel 4. Jenis-Jenis Vegetasi Pakan Kuskus yang Ditemukan Langsung Di lapangan

\begin{tabular}{llcc}
\hline \multicolumn{1}{c}{ Nama Jenis } & \multicolumn{1}{c}{ Famili } & $\begin{array}{c}\text { Jml } \\
\text { individu }\end{array}$ & Persentase \\
\hline Intsia sp. & Verbenaceae & 16 & 8,94 \\
Aglaia sp. & Meliaceae & 11 & 6,15 \\
Pimelodendron & Euphorbiaceae & 9 & 5,03 \\
amboinicum & Clusiaceae & 8 & 4,47 \\
Garcinia picrorhiza & Calophyllaceae & 6 & 3,35 \\
prostanum & Malvaceae & 6 & 3,35 \\
Sterculia macrophylla & Sapindaceae & 6 & 3,35 \\
Pometia sp. & 3 & 1,68 \\
Dracontumelon edule & Anonaceae & 2 & 1,12 \\
Syzygium malacensis & Myrtaceae & 2 & 1,12 \\
Garcinia sp. & Clusiaceae & 1 & 0,56 \\
Ficus sp. & Moraceae & 1 & 0,56 \\
Sterculia silinglawi & Malvaceae & 1 & \\
& &
\end{tabular}

Hasil analisis menunjukkan bahwa dari

12 jenis vegetasi pakan kuskus tersebut terdiri atas 71 individu $(39,66 \%)$ dari seluruh jumlah individu yang terdapat pada areal penelitian. Bila dibandingkan antara daya dukung habitat kuskus berdasarkan ketersediaan pakan dan kepadatan populasi kusku, maka dapat dinilai bahwa daya dukung habitat kuskus sesuai ketersediaan pakan adalah sangat melimpah. Hal tersebut dapat dinilai berdasarkan hasil estimasi produktivitas pakan dalam luasan tertentu terhadap populasi kuskus. Diketahui bahwa kemampuan konsumsi kuskus adalah $0,3-0,5 \mathrm{~kg} / \mathrm{ekor} / \mathrm{hari}$, bila dalam luasan 1 ha terdapat minimal 1 pohon pakan, maka dapat dinilai bahwa ketersediaan pakan tersebut adalah melimpah untuk populasi kuskus. Hal tersebut sesuai dengan pendapat Sinery dan Sutedjo (2009) yang menyatakan bahwa kemampuan konsumsi kuskus adalah 0,3-0,5 kg/ekor/hari, bila dalam 1 pohon (Ficus septica atau Syzygium sp.)memiliki produktivitas buah $30-50 \mathrm{~kg} /$ periode berbuah dengan frekuensi berbuah minimal 2 kali dalam setahun, maka ketersediaan pakan kuskus sangat melimpah untuk populasi kuskus dengan kapadatan 0,02 individu/ha. Secara keseluruhan dapat dinilai bahwa ketersediaan sumber pakan di kawasan hutan Pulau Numfor untuk kuskus adalah rendah bila dibandingkan dengan wilayah- wilayah lain yang menjadi habitat kuskus seperti di Pulau Moor Kabupaten Nabire dan Cagar Alam Pengunungan Arfak. Menurut Dimonmonmau (2000) sebanyak 32 jenis vegetasi diidentifikasi sebagai sumber pakan kuskus di Pulau Moor Kabupaten Nabire sedangkan menurut Sinery dan Sutedjo (2008) sebanyak 16 jenis vegetasi hutan yang diidentifikasi sebagai pakan kuskus di Cagar Alam Pegunungan Arfak.

Rendahnya jenis-jenis vegetasi pakan di Pulau Numfor tampaknya cukup berpengaruh terhadap keberadaan populasi kuskus di kawasan ini walaupun diperkirakan populasi kuskus di kawasan ini terus berkembang. Kondisi tersebut dapat dilihat dari frekuensi perburuan yang dapat mencapai 2 kali dalam seminggu dengan jumlah hasil buruan mencapai $2-3$ ekor per frekuensi berburu (hasil wawancara, 2011). Hal tersebut diduga karena melimpahnya sumber-sumber pakan areal-areal bekas kebun atau ladang yang didominasi oleh jambu-jambuan.

\section{Profil Vegetasi}

Secara umum vegetasi hutan jenis di Pulau Numfor merupakan formasi hutan dataran rendah yang didominasi jenis-jenis vegetasi dengan tinggi pohon berkisar antara 24 sampai $42 \mathrm{~m}$. Hasil pengukuran menunjukkan bahwa jenisjenis vegetasi di Pulau ini didominasi oleh jenisjenis seperti Intsia sp., Palaquium amboinensis, Dracontumelon edule, Horsfieldia laefigata, Pometia sp., Pimelodendron amboinicum, Garcinia spp dan beberapa jenis lainnya.

Berdasarkan hasil pengukuran terhadap kondisi profil tajuk pada petak ukur pertama $(20 \times 100 \mathrm{~m})$ yang selanjutnya dideskripsikan dalam bentuk gambar menunjukkan bahwa kondisi tutupan tajuk di plot ini adalah rapat. Hasil analisis pengukuran menunjukkan bahwa ukuran lebar tajuk terluas berturut-turut Intsia sp., Drancontumelon edule, Horsfielfia laefiga dan jenis-jenis lainnya. Hasil analisis proyeksi tajuk menunjukkan bahwa luas penutupan tajuk sebesar 72,5\%, termasuk kategori kelas 4 (rapat) dengan penutupan lebih dari $2 / 3$ dari luas petak contoh. 


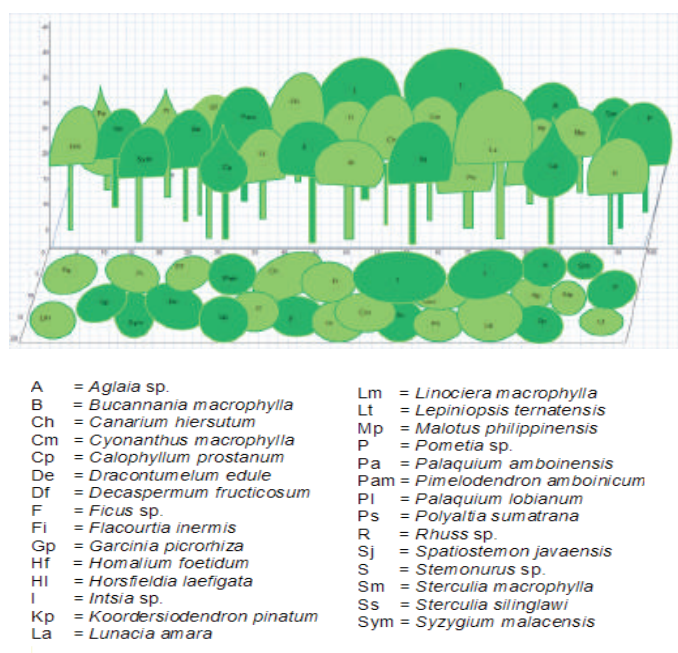

Gambar 4. Profil Tajuk Vegetasi Hutan pada Plot Ukur I

Kondisi profil tajuk pada petak ukur kedua (20 x $100 \mathrm{~m})$ yang selanjutnya dideskripsikan dalam bentuk gambar menunjukkan bahwa kondisi tutupan tajuk di plot ini sama dengan lokasi pertama yaitu rapat. Jenis-jenis dengan ukuran tajuk terluas berturut-turut Intsia sp., Drancontomelon edule, Horsfielfia laefiga dan jenis-jenis lainnya. Hasil analisis proyeksi tajuk menunjukkan bahwa luas penutupan tajuk sebesar $85,5 \%$, termasuk kategori kelas 4 (rapat) dengan penutupan lebih dari $2 / 3$ dari luas petak pengamatan (petak contoh).

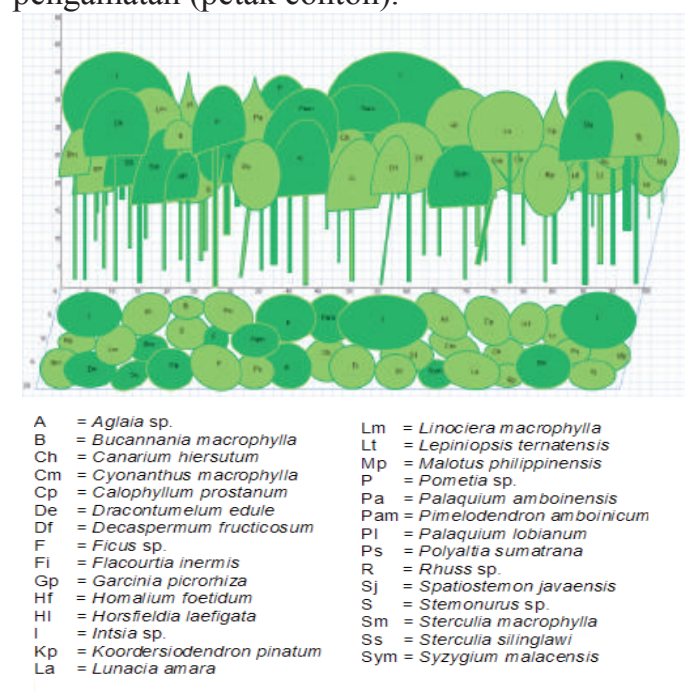

Gambar 5. Profil Tajuk Vegetasi Hutan pada Plot Ukur II
Hasil analisis tersebut menujukkan bahwa distribusi vegetasi pakan kuskus dalam setiap luasan tertentu adalah sama yaitu dapat dijumpai 5 -8 jenis pakan. Rendahnya kehadiran jenis-jenis pakan di kawasan hutan ini memberikan dampak terhadap adaptasi pakan kuskus yang mana satwa ini selalu bermigrasi untuk memperoleh makanan.

\section{KESIMPULAN}

Perkiraan kepadatan populasi kuskus di Pulau Numfor khususnya pada wilayah studi adalah 0,3 individu/ha. Angka ini masih lebih sedikit dibandingkan dengan penelitian kepadatan populasi kuskus ditempat lain, seperti di Cagar Alam Pengunungan Arfak.Kondisi vegetasi secara umum pada lokasi penelitian merupakan vegetasi hutan yang telah mencapai klimaks sehingga terlihat adanya dominasi jenis dan individu melalui Indeks Nilai Penting (INP) yang mana tingkat pohon lebih tinggi diikuti selanjutnya tingkat tiang, semai dan pancang. Ketersediaan pakan kuskus dilokasi penelitian mencapai $40 \%$ yang dianggap cukup rendah dan didominasi oleh jenis Intsia sp. dan Aglalia sp.Penutupan tajuk (tingkat pohon dan tiang) adalah cukup besar, yaitu antara $72,5 \%$ sampai dengan $85,5 \%$.Hasil dari pengamatan dengan penangkapan memberikan indikasi sex ratio antara jantan dan dan betina $6: 5$, dimana kondisi fisik kuskus jantan itu secara umum lebih besar dari pada betina. 


\section{DAFTAR PUSTAKA}

Alikodra, H.S. 1989. Pengelolaan Satwaliar Jilid I. Institut Pertanian Bogor, Bogor. 495 h

Alikodra , H.S. 1990. Pengelolaan Satwaliar Jilid I. Pusat Antar Universitas Ilmu Hayat, Institut Pertanian Bogor. Bogor

Alikodra, H.S. 1993. Pengelolaan Satwaliar Jilid II. Institut Pertanian Bogor, Bogor.

Anderson, S. And J.K. Jones. 1986. Recent Mammals of The World: A Synopsis of Families. The Ronald Press Company. United Stated of America.

Farida, W; G. Semiadi dan H. Dahruddin. 1999. Pemilihan Jenis-jenis Tumbuhan sebagai Tempat Bersarang dan Sumber Pakan Kuskus (Famili Phalangeridae) di Irian Jaya. Jurnal Biologi Indonesia 2 (5): 235-243.

Farida, W. 2001. Pemanfaatan Kuskus (Phalanger sp.) oleh Masyarakat Timor Barat, Nusa Tenggara Timur. Jurnal Biota 6 (2): $84-85$

Farida, W; Nurjaeni; R Mutia dan D. Diapari. 2004. Kemampuan Cerna Kuskus Beruang (Ailurops ursinus)terhadap Pakan Alternatif di Penangkaran. B i o s m a r $t$ (1):65-70

Flannery, T. dan G. Maynes. 1987. The Phylogenitic Relationships of Living Phalangerids (Phalangeroidea: Marsupialia) with a Sugested New Taxonomy. In Arther, M. (ed ). Possum and Opossum, Studies in Evolutions. Surrey Beatty \& Sons and The Royal Zoological Society of New South Wales, Sydney

Flannery, T. 1994. Possums of the World. A Monograph of the Phalangeroidea. Geo Production Pty Ltd, Australia. 249 h.

Flannery, T. 1995. Mammals of New Guinea. Australian Museum/Reed Books, Chatswood, NSW, Australia.

Kawer, P. 2001. Identifikasi Jenis Pakan Spilocuscus papuensis di Pulau Waigeo Kabupaten Sorong. Skiripsi Sarjana Kehutanan Fakultas Kehutanan Universitas Papua, Manokwari

Mandowen, H. 2004. Identifikasi Jenis Pakan Kuskus di Hutan Wisata Gunung Meja Kabupaten Manokwari. Skripsi Sarjana Kehutanan Fakultas Kehutanan Universitas Papua, Manokwari

Menzies J.I. 1991. A Handbook of New Guinea Marsupials and Monotermes. Kristen Pres Inc Papua New Guinea, Madang

Milad, M. 2007. Studi Awal Ketersediaan Pakan Dan Kondisi Habitat Untuk Kepentingan PelepasLiaran Owa (Hylobates Agilis Albibarbis Lyon.) DiHutan Hamaoak Kalimantan Tengah. Tesis Magister Kehutanan

Pattiselanno F, 2007. Perburuan Kuskus (Phalangeridae) oleh Masyarakat Napan di Pulau Ratewi, Nabire Papua. Jurnal Biodiversitas Universitas Sebelas Maret 8 (4):274-278.

Reumi, F. 2000. Strategi Pengelolaan Keanekaragaman Hayati. BAPEDALDA-WWF-NRM-CI, Manokwari.

Richards PW. 1964. The Tropical Rain Forest an Ecological Study. London: Cambridge of University London 
Riyanto, Nurkin B., Palenewan J.L., Suwondo, Delmi A, Renwarin J., Kladen P., Rahman M.N., Hatta G.M., 1985. Ekologi Dasar. Badan Kerjasama Perguruan Tinggi Negeri Indonesia Bagian Timur. Ujung Pandang.

Sailer, L.D. 1985. Measturing The Relationship Between Dietary Quailty and Bodysize in Primates. J.Primatology. Vol. 26 (1): 14-24

Sinery, A. 2002. Eksplorasi Jenis Kuskus Pulau Numfor Kabupaten Biak Numfor. Skripsi Sarjana Kehutanan Fakultas Kehutanan Universitas Papua, Manokwari. 79 h

Sinery, A. 2006. Jenis Kuskus di Taman Wisata Gunung Meja Kabupaten Manokwari. Jurnal Biodiversitas Universitas Sebelas Maret 7 (2):175-180.

Sinery, A. 2008. Studi Tentang Populasi Kuskus di Cagar Alam Pengunungan Arfak Kabupaten Manokwari Propinsi Papua Barat. Tesis Magister Kehutanan Universitas Mulawarman, Samarinda

Sinery, A. 2009. Pemanfaatan Kuskus Sebagai Protein Hewani di Papua. Cahaya Papua (7 Februari 2009).

Sinery, A. 2010. Populasi Spilocuscus maculatus di Arfak. (http://Theovane.blogspot_com/2010 03 01 archive. htlm). Diakses

Soegianto. 1994. Ekologi Kuantitatif: Metode Analisis Populasi dan Komunitas.

Tillman, A.D; R.H Soedomo; P. Soeharto dan L. Soekanto. 1986. Ilmu Makanan Ternak Dasar. Gadjah Mada University Press, Yogyakarta

Van Lavieren, L.P. 1982. Management of Conservation Areas. School of Enviromental Conservation. Management. Ciawi Bogor

Warmetan, H. 2004. Eksplorasi Jenis Kuskus pada Cagar Alam Pulau Yapen Tengah dan Distrik Yapen Selatan Kabuapten Yapen. Skripsi Sarjana Kehutanan Fahutan Universitas Papua, Manokwari 